\title{
ROLE OF PRODUCTIVE ZAKAT FUNDS ON MUSTAHIK MICRO BUSINESS DEVELOPMENT (CASE STUDY OF MEDAN CITY RUMAH ZAKAT)
}

\section{PERAN DANA ZAKAT PRODUKTIF TERHADAP PERKEMBANGAN USAHA MIKRO MUSTAHIK (STUDI KASUS RUMAH ZAKAT KOTA MEDAN)}

\author{
S.R.N.H Sinaga'; N. Adilla²; S.Sriani ${ }^{3}$
}

1,2,3 Jurusan Ekonomi Syariah Program Pascasarjana, Fakultas Ekonomi dan Bisnis Islam, Jl. William Iskandar Ps. V, Medan Estate, Kec. Percut Sei Tuan, Kabupaten Deli Serdang, Sumatera Utara 20371 Universitas Islam Negeri Sumatera Utara Email: srirezekinurhadiati26@gmail.com

\begin{abstract}
The aim of this research is to find out the role of productive zakat funds on mustahik business development. This research method uses descriptive method to find out the collection, management and empowerment of zakat fund system of Rumah Zakat Medan. To analyze the effects of zakat funds, productive capital, turnover, and profit / income from operations using different testing methods (Paired T-test). Objects in this study were given mustahik capital assistance by Zakat of 35 respondents. From the results of the study showed that an increase in mustahik income after getting capital assistance. This increase in business income shows the development of micro mustahik businesses which are also inseparable from the adnaya of assistance that is carried out regularly by Rumah Zakat.
\end{abstract}

Keywords: Rumah Zakat, Productive Zakat, Micro Business

\section{ABSTRAK}

Tujuan penelitian ini adalah untuk mengetahui peran dana zakat produktif terhadap perkembangan dana zakat mustahik. Metode penelitian ini menggunakan metode deskriptif untuk mengetahui sistem pengumpulan, manajemen dan pemberdayaan dana zakat Rumah Zakat Medan. Untuk menganalisis efek dari dana zakat, modal produktif, omset, dan laba / pendapatan dari operasi menggunakan metode pengujian yang berbeda (Paired $\mathrm{T}$-test). Objek dalam penelitian ini diberikan bantuan modal mustahik oleh Zakat sebesar 35 responden. Dari hasil penelitian menunjukkan bahwa adanya peningkatan pendapatan mustahik setelah mendapatkan bantuan modal. Peningkatan pendapatan usaha ini menunjukkan adanya perkembangan usaha mikro para mustahik yang juga tidak terlepas dari adnaya pendampingan yang dilaksanakan Rumah Zakat secara rutin.

Kata kunci: rumah zakat, zakat produktif, usaha mikro.

Sri Rezeki. 2020. Role Of Productive Zakat Funds In Mustahik Micro Business Development (Case Study of Medan City Rumah Zakat). Jurnal Syarikah 6(2): 130-136. 


\section{INTRODUCTION}

The purpose of economic development is to improve the welfare of the community. To carry out economic development can be done through the management of zakat funds properly. One type of zakat is productive zakat which is channeled through an empowerment program.

The existence of Micro Enterprises is expected to be able to provide a fairly good contribution to the problem of poverty and unemployment. At the regional level, especially the city of Medan, it can be seen that in general the economic growth of the city of Medan is inseparable from the contribution of MSMEs. This can be seen from the number of MSMEs that are quite a lot, with a number of approximately 242,890 MSME units consisting of types of business services trade, handicraft industry and various other businesses, where the institution has not been maximally arranged both in terms of licensing and legal aspects as well as from the access side to get capital so that the number of MSMEs in Medan is still uncertain.

The proportion of micro, small and medium entrepreneurs reaches $99.8 \%$ of the total economic businesses in the city of Medan. This means that the number of MSMEs reaches nearly 500 times the number of large businesses. However, the contribution of MSMEs to the city of Medan is estimated to only reach $39.8 \%$ while large businesses reach $60.2 \%$. This shows the strength of the large business sector and the still limited MSME sector (BPS North Sumatra, 2014).

There have been many attempts by the government to develop this productive business but in reality there are still many people who have not felt the assistance. Such as loans from government-owned banks or loans without collateral. Apart from the government, efforts to develop productive businesses are also assisted through microfinance institutions and
Islamic financial institutions. One of the Islamic financial institutions is the Amil Zakat Agency (BAZ) and the Amil Zakat Institution (LAZ) which is tasked with collecting and distributing funds to the public and is an official institution.

One of the Amil Zakat Institutions that has developed in Medan is one of the Zakat Houses. Rumah Zakat has the goal of being able to be a government partner in the MDG program, one of which is to improve welfare and improve community independence and improve the Human Development Index. The Mandiri Smile Program is the Rumah Zakat program with the concept of providing capital assistance to Mustahik. This program aims to help Mustahik Micro Enterprises that do not have venture capital.

From year to year LAZ Rumah Zakat has demonstrated its existence by developing four groups of empowerment programs, one of which is the Independent Smiles program in the form of empowering Micro, Small and Medium Enterprises (MSMEs). This program intensively conducts coaching and mentoring so that the business that is run experiences regular progress by mustahik beneficiaries.

\section{LITERATURE AND METHODS}

\section{Zakat}

The word zakat comes from the Arabic زكاة or zakah which means clean, holy, fertile, blessing, and growing. According to the term, zakat is a number of assets that must be issued by Muslims and given to groups who are entitled to receive it in accordance with established conditions. Zakat is the issuance of a certain portion of the property from certain assets which has reached the Nisab for those who are entitled to receive it.

The law of zakat is obligatory for capable Muslims. The law of zakat has also been explained in Law number 23 of 2011 article 1 and article 2 concerning zakat, which reads: zakat is a property that must be issued by a Muslim or business entity to 
be given to those entitled to receive it in accordance with Islamic law.

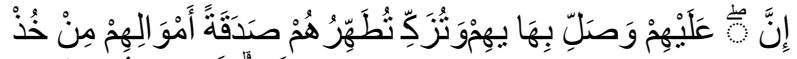

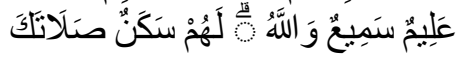

Meaning:

Take alms from some of their assets, with that you cleanse and purify them and pray for them. Verily, your prayers (become) peace of mind for them. And Allah is AllHearing, All-Knowing. Zakat has an important role in prospering and building community economic progress. Qardhawi (2002) states that zakat does not only have a limited role in poverty alleviation. However, it also aims to overcome other social problems. In line with that, the government through Law No. 23 of 2011 has set the objectives of zakat management, namely:

1. Increase the effectiveness and efficiency of services in the management of zakat. Good zakat management will facilitate the steps of an OPZ to achieve the core goal of zakati tu itself, namely the optimization of zakat. By acting efficiently and effectively, OPZ is able to make the most of existing zakat funds.

2. Increasing the benefits of zakat to realize community welfare and poverty reduction. In the provisions of Islamic law, the types of zakat are divided into two, namely:

a. Zakat Nafs (soul) or often called zakat fitrah which is zakat to purify oneself. Zakat fitrah can be in the form of staple food or in the form of money whose value is proportional to the staple food. The amount that must be spent for zakat fitrah is one sha '(one bushel), both for corn, dry wine, dates, wheat or other staples.

b. Zakat Mal (Zakat Asset) is a part of a person's assets that must be issued to a group of people who have been determined, after being owned for a certain period of time in a certain minimum amount.

In issuing zakat there are several mandatory requirements that must be met. Requirements that must be fulfilled are mandatory requirements and legal requirements. According to the agreement of the ulema the obligatory requirements of zakat are a Muslim, a baligh, independent, understanding, full ownership, reaching Nisab, and achieving haul. While the legal requirements also according to the agreement of the scholars are the intention that accompanies the implementation of zakat.

As for those who are entitled to receive zakat, it has been explained in Al-Quran surah At-Taubah verse 60:

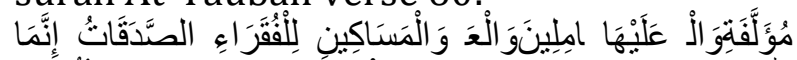

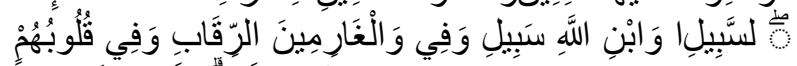

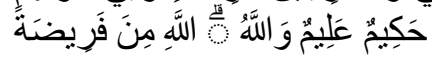

Meaning:

"Verily, the zakat is only for the needy, the poor, the administrators of zakat, the mu'allaf who are persuaded by their hearts, to (liberate) slaves, people who are in debt, for the way of Allah and for those who are on the way, as a decree required by Allah, and Allah knows the Wise. "

\section{Zakat Management Organization}

Distribution of zakat funds from muzakki (people who pay zakat) to mustahik (people who are entitled to receive zakat funds) will be more useful if channeled through zakat management organizations. Zakat management organization (OPZ) is an institution tasked with managing zakat, infaq, and shadaqah, both formed by the government such as BAZ, as well as those formed by the public and protected by governments such as LAZ. According to Law No. 23 of 2011 stated that, "Management of zakat is the activity of planning, implementation, and coordination in the collection, distribution, and utilization of zakat." Based on the legislation, in Indonesia there are two types of Zakat Management Organizations, namely the Amil Zakat Agency (BAZ) and Amil Zakat Institution (LAZ).

\section{Utilization of Zakat}

Zakat funds must be managed with management and professional management so that great potential can benefit the poor. So in the process of managing the most 
important management of zakat is the stage of allocation and distribution of zakat funds. In the distribution and distribution of zakat funds are divided into two, namely for consumptive zakat and for productive zakat. In general the distribution of zakat is distinguished based on the form of giving zakat and the use of zakat funds by mustahik. Each of the consumptive and productive needs is then divided into two, namely traditional consumptive and creative consumptive, while the productive form is divided into conventional productive and creative productive, namely: (1). Traditional Consumptive, (2). Creative Consumptive, (3). Conventional Productive, (4). Productive Creative

In utilizing zakat funds for productive activities, there are several procedures. The regulation is contained in Law No. 23 of 2011 concerning Management of Zakat, Chapter III article 27 include the following:

a. Zakat can be utilized for productive efforts in the context of handling the poor and improving the quality of the people.

b. Utilization of zakat for productive business is carried out if the basic needs of mustahiq have been met.

c. Further provisions regarding the utilization of zakat for productive business are regulated by Ministerial Regulation.

\section{Zakat In Earning Enterprises}

The word productive in language comes from productive English which means it produces a lot, gives a lot of results, produces many valuable items, which have good results. "Productivity" of production power. Productive zakat is distributing zakat funds to the mustahiq in a productive way. Zakat is given as venture capital, which will expand its business so that it can meet the necessities of life throughout life through economic activities that can grow and develop economic potential and productivity mustahiq.

With the capital the mustahik can increase their income through productive endeavors with the zakat funds they receive.
It is hoped that the structure of the community will change or with the aim of making Mustahik a muzakki.

Productive zakat funds are realized in the form of capital assistance to mustahik businesses. Productive zakat is zakat given by amil institutions to the people who need capital assistance, productive zakat funds as capital to carry out an economic activity that is to develop economic conditions and potential for mustahik productivity.

\section{Micro business}

The Micro, Small and Medium Enterprises (MSME) sector has a very important role in a country's economy. In Indonesia, MSMEs are the most common business activities carried out by the community. In addition to playing a role in economic growth and employment, MSMEs also play a role in distributing the results of development, income distribution and poverty reduction, and MSMEs also play a role in rural economic development.

\section{Methods}

In this study, the variables used are: (1) Business Capital; (2) Sales Turnover; (3) Business Benefits; (4) Capital Assistance. In this study two data collection methods were used, namely primary data and secondary data. The object of this research is the recipient of capital aid mustahik distributed by Medan City Zakat House. It is known that the number of mustahik recipients of zakat is 35 people, divided into two groups. Mustahik who is still actively running a business is only 30 mustahik. So the respondents of this study were 30 respondents. The method that will be used in this research is descriptive method to analyze the source and use of zakat funds and the management of productive zakat funds distributed by Medan City Zakat House. The study uses a different test analysis method to analyze the role of productive zakat funds on changes in consumption levels, business revenues and business profits of the people who get zakat fund channels. In describing this matter, different test of capital variable, sales turnover, and business profit of the respondent will be conducted using a paired T-test. 


\section{RESULT AND DISCUSSION}

Collection, Management and Distribution System of Productive Zakat at Zakat Houses. Management of zakat funds begins with planning, organizing, implementing, and supervising the collection and distribution and utilization of zakat. Zakat, infaq and shadaqah fund collection is done by various means, such as auto zakat (Infaq Card), zakat pick up, teledonation, zakat via swipe zakat, zakat via online banking, zakat via ATM, zakat via visiting counter.

In the case of zakat fund management, the Zakat House principles of zakat fund management are in accordance with government regulations regarding zakat fund management carried out by the Amil Zakat Agency and the Amil Zakat Institution, the utilization of the results of zakat collection for mustahik is based on the following requirements:

1. The results of income and truth research mustahik eight asnaf.

2. Give priority to the people who are most powerless to meet basic economic needs, and are in dire need of assistance.

3. Prioritize mustahik in their respective areas.

Rumah Zakat functions as an institution that only acts as a fundraiser and promotion program, while its implementation is handed over to 4 (four) foundations, namely Yayasan Mandiri Daya Insani, Indonesia Juara Foundation, Cita Sehat Foundation and Core Plus. In July 2012, Rumah Zakat employees who served as donation collectors will form a separate institution called Zakat Authorized Channel (ZAC) with an agency system. So the Rumah Zakat is technically only in the administrative and branding and promotion systems. In particular, the management structure of Rumah Zakat applies a top down pattern with the RAPB set by the central office.
The zakat funds obtained are then distributed through existing programs at Rumah Zakat with the BIG SMILE Indonesia program icon. The word BIG itself stands for "Sharing is Easy, Sharing is really mine", and "Sharing is Style". This BIG SMILE program characterizes Rumah Zakat as a creative philanthropic institution, in attracting the interest of donors to join Rumah Zakat. The BIG SMILE program is further divided into 4 smile programs:

1. Smile Champion, specifically the distribution of donations in the field of education.

2. Healthy Smiles, which specifically channel donations in the health sector.

3. Smile Mandiri, which in general donations are used for community empowerment activities in the productive economy of the Zakat House fostered community.

4. Smile Lestari, which uses donations for environmental preservation in each region.

Rumah Zakat engages in productive zakat in the form of providing capital assistance to mustahik. In providing capital assistance indirectly provided by the Zakat House. The process of selecting mustahik who is entitled to receive capital assistance is analyzed by the Zakat House. In the beginning the mustahik recipients of capital assistance amounted to 35 and until now the mustahik recipients of capital who are still actively running their businesses are 30 mustahik.

According to the management of the Alms Houses the number of mustahik recipients of capital is still 30 , this is because not all need capital, there are those who only need the help of business facilities and others based on the analysis of the Alms Houses.

There are several requirements and procedures that must be completed, namely (1) filling in forms, (2) filling in information already having a business or not, (3) type of business, (4) business constraints, (5) certificate of being unable, and (6) ) statement of commitment. After fulfilling all the criteria, 
the Zakat House will conduct a survey to the business location. After the mustahik is determined which is entitled to receive capital assistance, business monitoring is carried out, so that the business can be seen mustahik.

Monitoring is carried out with a visit from the Rumah Zakat to the recipient of the capital, which is conducted once a month. Mustahik is required to make a business registration book, from the book can be seen the development of mustahik business that will be reported to the head office. In addition to monitoring, the Zakat House also conducts various trainings such as business managerial training, bookkeeping, skills development training and motivation training.

One of the indicators of the success of the independent smile program is seen from the income of mustahik, from the one-year term of assistance provided there is an increase in income. Another indicator is seen from the managerial improvement of business and business completeness. The Zakat House party conducts monitoring of the mustahik business. In an effort to improve the independence and welfare of mustahik, Rumah Zakat does not only provide capital assistance to the mustahik, mustahik who is a member of Rumah Zakat also provides health services and free childbirth. Meanwhile, to improve the quality of education, Zakat House also provides Champion Schools for mustahik children.

Business Turnover Variable The results of different tests using the Paired T-test for business turnover variables, it can be seen that the results of the correlation between the two samples are worth 0.882 with a probability value of 0,000 less than 0.05 . It can be interpreted that the turnover relationship between before and after receiving capital assistance has a close or positive relationship. With the Paired T-test it is known that sig. (2tailed) for respondent capital $=0,000$ is less than 0.05. This means that the respondent's business turnover before and after receiving capital assistance is different. Providing venture capital assistance can significantly help in increasing the respondent's turnover.

\section{Profit Variable}

Business Difference test results using the Paired T-test variable profit / profit of the business is known the results of the correlation between two samples worth 0.935 with a probability value of 0,000 less than 0.05 . This can be interpreted that the capital relationship between before and after receiving capital assistance has a close or positive relationship. Viewed from the Paired T-test it is known that sig. (2tailed) for respondent's capital $=0.007$ is less than 0.05 . This means that the respondent's business profits / profits before and after receiving capital assistance are different. This means that providing business capital assistance can significantly increase the respondent's business profits.

Changes in Capital, Turnover, and Overall Benefits After and Before Getting Capital AidCapital assistance from productive zakat funds provides an important role for micro mustahik businesses. Mustahik who experiences capital constraints can be helped with productive zakat funds. Because the majority of Mustahik do not dare to borrow capital from formal institutions such as banks or cooperatives because of collateral. Capital assistance from productive zakat funds provides an important role for micro mustahik businesses. Mustahik who experiences capital constraints can be helped with productive zakat funds. Because the majority of Mustahik do not dare to borrow capital from formal institutions such as banks or cooperatives because of collateral

\section{CONCLUSION AND IMPLICATION}

Based on the results of discussions regarding the collection, management and collection of both zakat, infaq and sadaqah funds and the results of data analysis that have been carried out, it can be concluded that:

1. Collecting zakat funds, Rumah Zakat provides various facilities to muzakki, the collected zakat funds are all channeled to the program of independent smiles, champion smiles, healthy smiles and sustainable smiles. 
In the smile program itself uses the concept of providing capital assistance to mustahik who need capital assistance.

2. Based on the results of the Paired TTest, it can be seen that the capital, business turnover and profit of mustahik business are significantly different between before and after receiving venture capital assistance provided by Rumah Zakat.

\section{DAFTAR PUSTAKA}

An Nabhani, Taqiyuddin. (2010) Nidham AlIiqtishad Fi Al-Islam (Sistem Ekonomi Islam), Cet.4, diterjemahkan oleh Hafidz Abd Rahman., Jakarta: Hizbut Tahrir Indonesia.

Rozalinda. (2004). Ekonomi Islam : Teori dan Aplikasinya pada Aktivitas Ekonomi, Ed-1, Set,1, Jakarta: Rajawali Pers.

Syahrum, Salim. (2007). Metodologi Penelitian Kuantitarif, Bandung: Ciptapustaka Media.

Sukirno, Sadono. 2000. Pengantar Ekonomi Mikro. Jakarta: PT. Raja Grafindo Persada.

Suhehendi, Hendi. (2010). Fiqh Muamalah, Jakarta: Rajawali Pers.

Tambunan, Tulus. (2002). Usaha Kecil dan Menengah di Indonesia. Jakarta: Salemba empat.

Sintha, Achma. 2014. Analisis Peran Dana Zakat Produktif Terhadap Perkembangan Usaha Mikro Mustahik (Penerima Zakat) Studi Kasus Rumah Zakat Semarang. Jurnal Ekonomi, Vol III, No.1

www.Rumahzakat.org Sejarah, Program dan Layanan Rumah Zakat. Diakses 16 Maret 2020

www.Rumahzakat.org Laporan Keuangan ZIS Rumah Zakat Per 31 Desember 2017 dan 31 Desember 2018. Diakses 18 November 2020 